\title{
Working Capital Management: The Effect of Market Valuation and Profitability in Malaysia
}

\author{
Nor Edi Azhar Binti Mohamad \\ Department of Finance \& Economic, University Tenaga Nasional \\ Sultan Haji Ahmad Shah Campus, 26700 Muadzam Shah, Pahang, Malaysia \\ Tel: 60-9-455-2020-3324Ｅ-mail: NorEdi@uniten.edu.my \\ Noriza Binti Mohd Saad \\ Department of Finance \& Economic, University Tenaga Nasional \\ Sultan Haji Ahmad Shah Campus, 26700 Muadzam Shah, Pahang, Malaysia \\ Tel: 60-9-455-2020-3336 E-mail: noriza@ uniten.edu.my
}

\begin{abstract}
The paper is made with an attempt to bridge the gap in the literature by offering empirical evidence about working capital management and its effect to the performance of Malaysian listed companies from the perspective of market valuation and profitability. The secondary data for analysis is retrieved from Bloomberg's Database of 172 listed companies randomly selected from Bursa Malaysia main board for five year period from 2003 to 2007. The study aims to explore the effects of working capital component i.e cash conversion cycles (CCC), current ratio (CR), current asset to total asset ratio (CATAR), current liabilities to total asset ratio (CLTAR), and debt to asset ratio (DTAR) to the firm's performance by looking at firm's value i.e Tobin Q (TQ) and profitability i.e. return on asset (ROA) and return on invested capital (ROIC). Applying correlations and multiple regression analysis, the result shows that there are significant negative associations between working capital variables with firm's performance. Thus it highlights the importance of managing working capital requirements to ensure an improvement in firm's market value and profitability and this aspect must form part of the company's strategic and operational thinking in order to operate effectively and efficiently.
\end{abstract}

Keywords: Working Capital Management, Profitability, Tobin-Q and Cash Conversion Cycle

\section{Introduction}

The current squeeze on cash and credit is threatening the survival of many businesses in all over the world primarily in Malaysia, as it's considered the sources of company's working assets and the liabilities or collectively referred to as working capital. The facts that corporations could not exist without working capital is thus, undeniable. Eventually, the management of working capital (WCM) necessitates short term decisions in working capital (WC) and financing of all aspects of both firm's short-term assets and liabilities. The main objective is to ascertain that firm has the ability to continue operating with sufficient cash flow for payment of both maturing short-term debt and impending operational expenses. Consequently, its involve crucial decisions on multiple aspects, including managing account payables and account receivables, preserving a certain level of inventories and the investment of accessible cash. In view of that, working capital management has become one of the most important issues in the organizations where many financial executives strive to identify the basic working capital drivers and the appropriate level of working capital (Lamberson, 1995).

Thus, its requirements are having an impact on the market valuation of a business, which in erratic times falls under even greater analysis by shareholders and investors and its had been point out that an efficient working capital management has becoming an essential element of the overall corporate strategy to create shareholder value (Shin and Soenen, 1998 and Afza and Nazir, 2007). According to Ganesan, (2007), optimization of working capital balance means minimizing the working capital requirements and realizing maximum possible revenues. Further, efficient WCM increases firms' free cash flow, which in turn increases the firms' growth opportunities and return to shareholders. Thus, firms try to keep an optimal level of working capital that maximizes their value (Afza and Nazir 2007) and the efficient management of working capital is likely to yield significant results and its neglect can be highly dangerous to any firm (Christopher and Kamalavalli, 2009). The 
significant of WC had been highlighted in most of the literature of WCM.i.e Eljelly (2004) described that the efficient WCM are engaged with planning and controlling current assets and liabilities in such a way that eliminates the risk of inability to meet short-term obligations in hands with the avoidance of excessive investments in these assets. Siddiquee and Khan (2009) indicate that the inefficient management of WC not only reduces profitability but ultimately may also lead a concern to financial crisis thus every organization, irrespective of its profit orientation, size and nature of business, needs requisite amount of WC. Consequently, the efficient WCM is the most crucial factor in maintaining survival, liquidity, solvency and profitability of the concerned business organization. Thus, we could say that approach in managing working capital has enormous influence to the firm's performance.

Extensive empirical research on WCM was carried out worldwide by the academia in order to hypothesize firms' performance (see example, Shin and Soenen, 1998; Narware, 2004; Lazaridis and Tryfonidis, 2006; Padachi, 2006; Sayaduzzaman, 2006; Afza and Nazir, 2007; Chowdhury and Amin, 2007; Ganesan, 2007; Raheman and Nasr, 2007; Christopher and Kamalavalli, 2009 and Uyar, 2009). Even so, the impact of various working capital mechanisms on firm's performance from Malaysia perspective might be vaguely difference due to the divergence in business environment between other countries. Considering the potential contribution of WCM to firm performance which eventually related to the economy of Malaysia, therefore, the objective of our study is to discover the relationships between working capital management with firm's value and profitability in a sample of Malaysian listed companies.

Since earlier study was built on western data and specific research studies exclusively on the impact of working capital on firm value and profitability of companies in Malaysia are scanty, thus this study was conducted with an attempt to bridge the gap in the literature by offering empirical evidence to the extent of which the result in Malaysia would be parallel to past studies. Furthermore, this study is hope to brings benefit where the result can contribute to the body of knowledge by identifying how market value and profitability of Malaysian companies effected by their working capital. The findings of this study is also hope to provide an insight for concerned managers on the company's WCM policy since it's provide an important role in its profitability by furnish more attention towards WCM.

\section{Literature Review}

The importance of WCM is not new to the finance literature and the review of prior literature reveals that there exists a significant relation between performance and working capital management by using different variable selection for analysis. Ganesan, (2007) analyze the working capital management efficiency of firms from telecommunication equipment industry. The variables used to represent the working capital are day's sales outstanding, days inventory outstanding, days payable outstanding, days working capital, and current ratio while profitability and liquidity represent by cash conversion efficiency, income to total assets and income to sales. This study found evidence that even though "day's working capital" is negatively related to the profitability, it is not significantly impacting the profitability of firms in telecommunication equipment industry. While, Chowdhury and Amin (2007) had found positive correlations between WCM with financial performance of the Pharmaceutical industry in Bangladesh. Whereas, Narware (2004) in his empirical study on Indian National Fertilizer Limited, for 1990-91 to 1999-2000 signify that working capital management and profitability of the company disclosed both negative and positive association. He also found evidence that increase in the profitability of a company was less than the proportion to decrease in working capital.

However, the study done by Raheman \& Nasr, (2007) on a sample of 94 Pakistani firms listed on Karachi Stock Exchange for a period of 6 years from 1999 - 2004, demonstrate a strong negative relationship exists between variables of the working capital management represents by liquidity and debt with profitability of the firm. Whilst, Afza and Nazir (2007) through cross-sectional regression models on working capital policies, profitability and risk of the firms, found a negative relationship between the profitability measures of firms and degree of aggressiveness on working capital investment and financing policies. Their result indicates that the firms yield negative returns if they follow an aggressive working capital policy by investigating the relative relationship between the aggressive or conservative working capital policies for 208 public limited companies listed at Karachi Stock Exchange for a period of 1998-2005. Padachi (2006) founds that high investment in inventories and receivables is associated with lower profitability. He used return on total assets as a measure of profitability for a sample of 58 small manufacturing firms in Mauritius for the period $1998-2003$. The findings also reveal an increasing trend in the short-term component of working capital financing. Similar to most recent study by Christopher and Kamalavalli, (2009), which focus on 14 corporate hospitals in India for the period 1996-97 to 2005-06. Their correlations and regression analysis signifying that working capital component namely current ratio, cash turnover ratio, current assets to operating income and leverage negatively influence 
profitability.

The cash conversion cycle had been widely used as a major component represents working capital. One of the earlier studies done by Jose, Lancaster and Stevens(1996) for the twenty-year period from 1974 through 1993 of 2,718 firms offers strong evidence that aggressive working-capital policies indicate by shorter cash conversion cycle enhance profitability. Similar to Lazaridis and Tryfonidis (2006) that showed there is a statistical significance between profitability, measured through gross operating profit, and the cash conversion cycle using the sample of 131 companies listed in the Athens Stock Exchange (ASE) for the period of 2001-2004. Recent study by Uyar (2009) also found a significant negative correlation between the CCC with profitability measured by return on asset but not significant with return on equity. By utilizing ANOVA and Pearson correlation analyses of the corporations listed in the Istanbul Stock Exchange (ISE) for the year 2007, he indicates that the firms with shorter CCC are more likely to be more profitable than the firms with longer CCC.

Although the issue on WC has been widely studied, largely missing from literature is the focus on firm's market valuation. Kieschnick, LaPlante. and Moussawi (2008), found that the important of working capital management to firm value, using data on a panel of U.S. corporations from 1990 through 2004. Their study used stock's excess return to represent the firm value and finding shown that on average an additional dollar invested in net operating working capital reduces firm value and indicates that their study is consistent with industry surveys suggesting that some firms over-invest in net operating working capital. Nazir (2009) analyzed on the impact of aggressiveness of working capital investment and financing policies in Pakistan for a sample of 204 non-financial firms listed at Karachi Stock Exchange for the period of 1998-2005. They evaluated on firm returns i.e. return on assets and Tobin's q to represent market performance and indicates that firms adopting an aggressive approach towards working capital financing policy giving more value to the firms while inverse relationship between the aggressiveness of working capital investment policies on firms performance. These results are consistent with Afza and Nazir (2007) that using Tobin's Q to represents stock market performance of Karachi Stock Exchange. They point out that efficient management of working capital is associated to the stock market performance.

Turning to the empirical literature on working capital management, we found a limited published study on the consequences of working capital management on firm's performance from Malaysia perspectives. Irene \& Lee, (2007) explores the prevailing working capital management practices of some well-performed Malaysian public firms listed on Bursa Malaysia. They examine the correlation between profitability and the level of working capital of the sample firms and founds that profitability and working capital are linearly related positively to a certain extent. All the above studies provide us a solid base and give us idea regarding working capital management and its components. They also give us the results and conclusions of those researches already conducted on the same area for different countries and environment from different aspects. On basis of these researches done in different countries, we have developed our methodology for research.

\section{Research Methodology}

The study used only secondary data, which are retrieved from Bloomberg's Database from a sample of 172 randomly selected from the list of companies listed in Bursa Malaysia. The sample interval is for five- year period from 2003 to 2007. Ratio analysis was chosen as a performance measurement and indicators since this analysis provides methods for assessing the financial strengths and weaknesses of the firms performance using information found in its financial statements. Three measures of firms performance used by previous studies in corporate performance and working capital literature have been identified as independent variables namely Tobin $\mathrm{Q}$ as a proxy for market value, while return on asset and return on invested capital as the proxy for profitability. Profitability is used as a measurement for corporate performance because it evaluates the efficiency with which plant, equipment, and current assets are transformed into profit (Kamal and Mohd Zulkifli, 2004). The independent variables representing working capital components identified to assess their impact on firm's performance are cash conversion cycles (CCC), current ratio (CR), current asset to total asset ratio (CATAR), current liabilities to total asset ratio (CLTAR), and debt to asset ratio (DTAR). The formula for calculating these values are given in the following table 1.

By using the Statistical Package of Science Social (SPSS) programs, the relation between the variables had been examined by making use the Correlation and Multiple Regression analysis. Three alternate hypotheses had been developed to find the significant relations between working capital variable with profitability;

Hypothesis H1: There is an association between Tobin $Q$ and Working Capital components.

Hypothesis H2: There is an association between Return on Asset and Working Capital components. 
Hypothesis H3: There is an association between Return on Invested Capital and Working Capital components.

The regression models to be estimated to test the hypothesis are:

$\mathrm{TQ}_{i t}=\beta_{0}+\beta_{1} \mathrm{CCC}_{i t}+\beta_{2} \mathrm{CACLR}_{i t}+\beta_{3} \mathrm{CATAR}_{i t}+\beta_{4} \mathrm{CLTAR}_{i t}+\beta_{5} \mathrm{DTAR}_{i t}+\varepsilon$

$\mathrm{ROA}_{i t}=\beta_{0}+\beta_{1} \mathrm{CCC}_{i t}+\beta_{2} \mathrm{CACLR}_{i t}+\beta_{3} \mathrm{CATAR}_{i t}+\beta_{4} \mathrm{CLTAR}_{i t}+\beta_{5} \mathrm{DTAR}_{i t}+\varepsilon$

$\mathrm{ROIC}_{i t}=\beta_{0}+\beta_{1} \mathrm{CCC}_{i t}+\beta_{2} \mathrm{CACLR}_{i t}+\beta_{3} \mathrm{CATAR}_{i t}+\beta_{4} \mathrm{CLTAR}_{i t}+\beta_{5} \mathrm{DTAR}_{i t}+\varepsilon$

Where,

$\mathrm{TQ}_{i t}=$ market value of firm $\mathrm{i}$ for time period $\mathrm{t}$

$\mathrm{ROA}_{i t}=$ return on assets of firm $\mathrm{i}$ for time period $\mathrm{t}$

ROIC $_{i t}=$ return on invested capital of firm $\mathrm{i}$ for time period $\mathrm{t}$

$\mathrm{CCC}_{i t}=$ cash conversion cycle of firm i for time period $\mathrm{t}$

$\mathrm{CACLR}_{i t}=$ current asset to current liabilities ratio of firm $\mathrm{i}$ for time period $\mathrm{t}$

$\mathrm{CATAR}_{i t}=$ current assets to total assets ratio of firm $\mathrm{i}$ for time period $\mathrm{t}$

$\mathrm{CLTAR}_{i t}=$ current liabilities to total asset ratio of firm i for time period $\mathrm{t}$

$\mathrm{DTAR}_{i t}=$ total debt to total assets ratio of firm i for time period $\mathrm{t}$

$\varepsilon=$ error term of the model

\section{Results and Analysis}

\subsection{Correlation Analysis}

The correlations between the variables are reported in table 2. Results indicate no multicollinearity problems, as the correlations are relatively low. As according to Gujarati (1995), multicollinearity problems exist when the correlations value exceeded 0.80 . The correlations results for TobinQ indicate positive coefficient with CATAR $(+0.172)$, CLTAR $(+0.103)$ and DTAR $(+0.107)$ all at $1 \%$ significant level, but positive insignificant with CACLR (0.011), while, negative coefficient with CCC (-0.086) at 5\% significant level. As for ROA, results demonstrate positive coefficient with CACLR $(+0.183)$ and CATAR $(+0.293)$ at $1 \%$ level, whilst, negative significant coefficient at $1 \%$ level with CCC (-0.154), CLTAR (-0.078), and DTAR (-0.247). The correlations between ROIC with CACLR $(+0.064)$, CATAR $(+0.379)$,and CLTAR $(+0.203)$ also indicating positive significant coefficient at $10 \%, 1 \%$ and $1 \%$ level respectively whereas viewing negative significant coefficient with CCC $(-0.135)$, at $1 \%$ level and DTAR (-0.063) at 10\% level. Overall the correlations results indicates both alternate hypotheses 1, 2 and 3 can be accepted implying a significant correlations exist between WC components with market value and firm's profitability.

\subsection{Regression Analysis}

However, examining simple bivariate correlation in a conventional matrix does not take into account of each variable's correlation with all other explanatory variables. To test the effects of working capital on firm value and profitability, a regression analysis are given using 860 firm-years observations and the results is presented in table 3. According to Table 3, CCC has a negative association with Tobin Q, ROA and ROIC at $1 \%$ significant level. The result for ROA is consistence with the study done by Uyar (2009), Martínez-Solano and García-Teruel, (2006), and Jose, Lancaster and Stevens (1996) while, no published study is found in term of CCC with TobinQ and ROIC. However, the study done by Shin and Soenen (1998), Lazaridis and Tryfonidis (2006), and Raheman and Nasr (2007) also indicating an inverse relations between CCC with profitability of firms measured by others variable. Our findings thus support all the three hypothesis indicating that any increase in TobinQ, ROA and ROIC can be explained by a reduction in CCC and this entail that most of the profitable firms have a shorter CCC. As indicate by Uyar (2009), firms with shorter CCC will not required an external financing thus resulted in less borrowing cost and this consequently will increase the profitability. Further, according to Lazaridis and Tryfonidis (2006), the three different components of CCC i.e. accounts payables, accounts receivables and inventory managed in diverse ways will facilitate a profit maximization and enhancement of companies growth.

As for the CACLR, the result stipulate a $1 \%$ confidence to be negatively related with ROA and ROIC but negatively insignificant with TobinQ. This indicate that any increase in both ROA and ROIC can be explained by a reduction in CACLR but not for Tobin thus, support hypothesis 2 and 3, as the effect of CR is negatively significant with ROA and ROIC. We could say that positive return of the firms can be obtained by reducing the CACLR. The current study is corroborate with Christopher and Kamalavalli (2009) and Shin and Soenen (1998) however reverse to the study done by Sayuddzaman, (2006) which found positive association with performance. 
The regression results for CATAR indicate a $1 \%$ confidence having positive association with TobinQ, ROA and ROIC indicating any increase in TobinQ, ROA and ROIC can be explained by an increased in CATAR thus support hypotheses 1, 2 and 3. We mentioned here the study done by Nazir, (2009), Afza \& Nazir, (2007) which indicate similar results for Tobin Q and ROA, while results for ROIC is similar with Christopher and Kamalavalli (2009) and Narware (2004). Based on the results, it can be assumed that listed firms in Malaysia tend to rely most on the tendency of currents asset to generate profit thus they have to sustain an optimum daily requirements of currents assets in addition to meet their short term maturities, or else profitability will be decreased severely.

As depicted by the results of CLTAR, the analysis indicate negative associations with TobinQ and ROIC both at $10 \%$ confidence level while $1 \%$ negatively significant with ROA. This shows that the lower the ratio will increase the firm's performance which support the entire three hypothesis, as the changes in TobinQ, ROA and ROIC can be explained by the changes in CLTAR. The results for ROA confirms the study by Nazir, (2009) and Afza \& Nazir, (2007) while TobinQ contradict to Afza \& Nazir, (2007) and Nazir, (2009).

As for DTAR in relations with the firms performance in Malaysia is concerned disclosed mixed results where there was a positive association with TobinQ at $1 \%$ significant level and negative associations with ROA at $\%$ significant level. However the result for ROIC (-0.634) depicted a negative insignificant associations with DTAR. This implies that the increase or decrease of debt level will significantly affect the firm's performance, which means that reducing the debt level will significantly increase the ROA and reducing the TobinQ. These results thus support our Hypothesis 1 and 2 for TobinQ and ROA but not Hypothesis 3 for ROIC where any changes in TobinQ and ROA can be explained by the changes in DTAR but changes in DTAR cannot explain the changes in ROIC. Our result is similar to the study done by Shin and Soenen (1998), Padachi (2006) and Christopher and Kamalavalli (2009) which also initiate a negative association with profitability.

\section{Conclusion}

In this paper we make an empirical research on the associations between working capital management with firm's performance. The study employed three model specifications in order to test the postulated hypotheses, using market value measure of TobinQ and profitability measured by return on invested capital (ROIC) and return on asset (ROA) along with other independent variables for 172 selected listed companies in Bursa Malaysian for the period of 2003 until 2007. On the basis of findings of the research, it can be conclude that there are significant relations between WCM with firm's performance as findings suggested that, working capital components and performance in Malaysia disclose both positive and negative association. The study revels that out of five components selected for the study, CATAR shows positive significant relationships with TobinQ, ROA and ROIC. Whereas, three components (CCC, CACLR and CLTAR) illustrate negative significant relations with TobinQ, ROA and ROIC, whilst, DR is negatively significant with ROA only but insignificant with ROIC, while positively significant with TobinQ.

The regression results support hypotheses 1 , hypotheses 2 and hypotheses 3 as depicted by table 3, the $\mathrm{F}$ statistics is substantiated at the $1 \%$ significant level for TobinQ(F=11.761) $\operatorname{ROA}(\mathrm{F}=53.606)$ and $\mathrm{ROIC}(\mathrm{F}=41.089)$ implying the null hypotheses that the regressions coefficients are all zeros can be rejected at $1 \%$ level of significant. Though, the $\mathrm{R}$ squared (Tobin $\mathrm{Q}=0.254$; $\mathrm{ROA}=0.489$ and $\mathrm{ROIC}=0.440$ ) and adjusted $\mathrm{R}$ square (TobinQ $=0.064 ; \mathrm{ROA}=0.239$ and $\mathrm{ROIC}=0.194$ ) statistically shows weak relationships for the three hypotheses tested, however, the estimated regressions is efficient for predictions and the hypotheses 1, hypotheses 2 and hypothesis 3 can be accepted implying that there are an associations between working capital variables with the market value and profitability of listed companies in Malaysia. In conclusions, applying correlations and multiple regression analysis, the result shows that there are significant negative associations between working capital variables with firm's market value and profitability. Thus it highlights the importance of managing working capital requirements to ensure an improvement in firm's market value and profitability and this aspect must form part of the company's strategic and operational thinking in order to operate effectively and efficiently. Although all the alternate hypotheses are support by the analysis, however the results of present study are in contradiction to some earlier studies on the issues. Nevertheless, we hope that the result can contribute to the body of knowledge by identifying how market value and profitability of Malaysian companies effected by their working capital. It was recommended that the study is further improved with more sample size, different variables for working capital practices and also other external variable which might provide a strong relationship between the variables and help to uncover the better firm's performance in Malaysia perspectives. Thus this study is left for future to be further explored. 


\section{References}

Abdul Raheman \& Mohamed Nasr. (2007). Working capital management and profitability - case of pakistani firms. International Review of Business Research Papers, Vol.3 (2), pp. 275 - 296.

Afza T., \& Nazir, M.S. (2007). Is it better to be aggressive or conservative in managing working capital?, Paper presented at Singapore Economic Review Conference (SERC) on August 02-04, Singapore

Chowdhury, Anup \& Amin, Md. Muntasir. (2007). Working capital management practiced in pharmaceutical companies listed in Dhaka stock exchange. BRAC University Journal, Vol. IV, No. 2, 2007, pp. 75-86

Christopher, S. B., and Kamalavalli, A. L. (2009). Sensitivity of profitability to working capital management in Indian corporate hospitals. [Online] Available: http://ssrn.com/abstract=1331500

Eljelly, A. (2004). Liquidity-profitability tradeoff: an empirical investigation in an emerging market. International Journal of Commerce and Management, Vol.14 (2), pp. 48- 61.

Ganesan, Vedavinayagam. (2007). An analysis of working capital management efficiency in telecommunication equipment. Industryrivier Academic Journal, 3, No. 2, Fall.

Gujarati, D. (1995). Basic Economics, McGraw-Hill Singapore.

Hyun-Han Shin \& Luc Soenen. (1998). Efficiency of working capital management and corporate profitability, Journal of Financial Practice and Education, Vol.8 (2), pp. 37 - 45.

Irene T.W.K \& Lee S. F. (2007). An empirical exploration into optimal working capital management on public listed companies in Malaysia, Proceedings of the $3^{\text {rd }}$ UNITEN International Business Conference (UIBMC), 16-18 December, Malaysia.

Jose M.L, Lancaste, C \& Stevens, J.L. (1996). Corporate returns and cash conversion cycles. Journal of Economics and Finance, 9 Volume 20, Number I, Pages 33-46

Kamal, N., \& Mohd Zulkifli, M. (2004). Determinants of corporate performance of Malaysian companies, Accepted for Presentation at the Fourth Asia Pacific Interdisciplinary Research in Accounting Conference 4 to 6 July 2004

Kieschnick.R, LaPlante.M \& Moussawi.R. (2008). Working capital management, agency costs, and firm value. [Online] Available: http://www.fma.org/Texas/Papers/valnowc_fma2008.pdf.

Lamberson M. (1995). Changes in working capital of small firms in relation to changes in economic activity. Mid-American Journal of Business 10(2): 45-50.

Lazaridis I \& Tryfonidis, D. (2006), Relationship between working capital management and profitability of listed companies in the Athens stock exchange, Journal of Financial Management and Analysis, Vol.19 (1), pp 26 - 35.

Martínez-Solano, Pedro \& García-Teruel, Pedro J. (2006). Effects of working capital management on sme profitability. [Online] Available: http://ssrn.com/abstract $=894865$

Narware P. C. (2004). Working capital and profitability- an empirical analysis. The Management Accountant, Vol, 39 (6), pp 120-127.

Nazir, M.S. (2009). Impact of working capital aggressiveness on firms' profitability. IABR \& TLC Conference Proceedings, San Antonio, Texas, USA.

Padachi, Kesseven. (2006). Trends in working capital management and its impact on firms' performance: an analysis of Mauritian small manufacturing firms. International Review of Business Research Papers, Vol. 2 (2), pp. 45 - 58.

Raheman, Abdul \& Mohamed Nasr. (2007). Working capital management and profitability- case of Pakistani firms. International Review of Business Research Paper, 3.1,pp.279-300.

Sayuddzaman, Md. (2006). Working capital management: A study on British American Tobacco Bangladesh Company Ltd'. The Journal of Nepalese Business Studies, III, No. 1

Siddiquee, Moniruzzaman \& Khan, Shaem Mahmud, (2009). Analyzing working capital performance: evidence from dhaka stock exchange (dse) ltd), [Online] Available: http://ssrn.com/abstract=1374210.

Uyar, Ali. (2009). The relationship of cash conversion cycle with firm size and profitability: an empirical investigation in Turkey. International Research Journal of Finance and Economics, ISSN 1450-2887 Issue 24, EuroJournals Publishing, Inc. 


\section{Appendix}

Table 1. Notations and measures used for all variables in the study

\begin{tabular}{|c|c|c|}
\hline Variable Name & Notation & Description \\
\hline \multicolumn{3}{|l|}{ Dependents Variables; } \\
\hline 1. Tobin-Q & TQ & $\begin{array}{l}\text { (market value of equity }+ \text { book value of } \\
\text { liability) } / \text { total assets }\end{array}$ \\
\hline 2.Return on Asset & ROA & earning before interest tax/ total asset \\
\hline 3. Return on Invested Capital & ROIC & net income/ total capital \\
\hline \multicolumn{3}{|l|}{ Independents Variables; } \\
\hline 3. Cash Conversion Cycle & $\mathrm{CCC}$ & $\begin{array}{l}\text { days sales in inventory }(\mathrm{DSI})+\text { days sales } \\
\text { outstanding (DSO) }- \text { days payables } \\
\text { outstanding (DPO); } \\
* \mathrm{DSI}=\text { inventories/ (COGS/days in year) } \\
* \mathrm{DSO}=\text { receivables/ (sales/days in year) } \\
* \mathrm{DPO}=\text { payables/ (COGS/days in year) }\end{array}$ \\
\hline 4. Current Asset to Current Liability Ratio & CACLR & current asset/ current liabilities \\
\hline 5.Current Asset To Total Asset Ratio & CATAR & current asset/ total asset \\
\hline 6.Current Liability to Total Asset Ratio & CLTAR & current liability / total asset \\
\hline 7. Total Debt to Total Asset Ratio & DTAR & total debt/ total asset \\
\hline
\end{tabular}

Table 2. The Pearson Correlations Matrix

\begin{tabular}{|l|l|l|l|l|l|l|l|l|}
\hline VARIABLES & TobinQ & ROA & ROIC & CCC & CACLR & CATAR & CLTAR & DTAR \\
\hline TobinQ & 1 & $.308^{* * *}$ & $.398^{* * *}$ & $-.086^{* *}$ & .011 & $.172^{* * *}$ & $.103^{* * *}$ & $.107^{* * *}$ \\
& & .000 & .000 & .012 & .737 & .000 & .002 & .002 \\
\hline ROA & $.308^{* * *}$ & 1 & $.631^{* * *}$ & $-.154^{* * *}$ & $.183^{* * *}$ & $.293^{* * *}$ & $-.078^{* *}$ & $-.247^{* * *}$ \\
& .000 & & .000 & .000 & .000 & .000 & .023 & .000 \\
\hline ROIC & $.398^{* * *}$ & $.631^{* * *}$ & 1 & $-.135^{* * *}$ & $.064^{*}$ & $.379^{* * *}$ & $.203^{* * *}$ & $-.063^{*}$ \\
& .000 & .000 & & .000 & .061 & .000 & .000 & .066 \\
\hline CCC & $-.086^{* *}$ & $-.154^{* * *}$ & $-.135^{* * *}$ & 1 & $.089^{* * *}$ & $.179^{* * *}$ & .018 & $-.067^{* *}$ \\
& .012 & .000 & .000 & & .009 & .000 & .602 & .050 \\
\hline CACLR & .011 & $.183^{* * *}$ & $.064^{*}$ & $.089^{* * *}$ & 1 & $.333^{* * *}$ & $-.280^{* * *}$ & $-.358^{* * *}$ \\
& .737 & .000 & .061 & .009 & & .000 & .000 & .000 \\
\hline CLTAR & $.172^{* * *}$ & $.293^{* * *}$ & $.379^{* * *}$ & $.179^{* * *}$ & $.333^{* * *}$ & 1 & $.530^{* * *}$ & $-.151^{* * *}$ \\
& .000 & .000 & .000 & .000 & .000 & & .000 & .000 \\
\hline DTAR & $.103^{* * *}$ & $-.078^{* *}$ & $.203^{* * *}$ & .018 & $-.280^{* * *}$ & $.530^{* * *}$ & 1 & $.251^{* * *}$ \\
& .002 & .023 & .000 & .602 & .000 & .000 & & .000 \\
\hline
\end{tabular}

Significant at $1 \%$ level $* * \quad$ Significant at $5 \%$ level

Significant at $10 \%$ level 
Table 3. Linear multiple regression coefficients with dependent variables; Tobin Q (TQ), return on asset (ROA) and return on invested capital (ROC)

\begin{tabular}{|l|l|l|l|l|l|l|}
\hline $\begin{array}{l}\text { Dependent } \\
\text { Variable }\end{array}$ & $\begin{array}{l}\text { Eq. 1 } \\
\text { TOBINQ }\end{array}$ & \multicolumn{2}{l|}{$\begin{array}{l}\text { Eq. 2 } \\
\text { ROA }\end{array}$} & \multicolumn{2}{l|}{$\begin{array}{l}\text { Eq.3 } \\
\text { ROIC }\end{array}$} \\
\hline $\begin{array}{l}\text { Independent } \\
\text { Variable }\end{array}$ & $\mathrm{t}$ & $\mathrm{P}$ & $\mathrm{t}$ & $\mathrm{P}$ & $\mathrm{t}$ & $\mathrm{P}$ \\
\hline CCC & $-3.564^{* * *}$ & .000 & $-8.024^{* * *}$ & .000 & $-6.812^{* * *}$ & .000 \\
\hline CACLR & -1.014 & .311 & $-3.454^{* * *}$ & .001 & $-2.809^{* * *}$ & .005 \\
\hline CATAR & $5.568^{* * *}$ & .000 & $12.340^{* * *}$ & .000 & $10.595^{* * *}$ & .000 \\
\hline CLTAR & $-1.883^{*}$ & .060 & $-8.391^{* * *}$ & .000 & $-1.785^{*}$ & .075 \\
\hline DTAR & $4.057^{* * *}$ & .000 & $-3.988^{* * *}$ & .000 & -.634 & .526 \\
\hline R & 0.254 & & 0.489 & & 0.440 & \\
\hline R Square & 0.064 & & 0.239 & & 0.194 & \\
\hline F-Value & $11.761^{* * *}$ & & $53.606^{* * *}$ & $41.089^{* * *}$ & \\
& 0.000 & & 0.000 & & 0.000 & \\
\hline
\end{tabular}

**** Significant at $1 \%$ level ** $\quad$ Significant at $5 \%$ level * Significant at $10 \%$ level 